\title{
腰部椎間板ヘルニアに対する観血的治療例の術後検討
}

済生会熊本病院整形外科
$\begin{array}{llll}\text { 有 村 一 } & \text { 盛・高 良 } & \text { 健 } \\ \text { 福 山 } & \text { 紘・松 岡 正 敏 }\end{array}$

\section{Clinical Results of Surgical Treatment of the Lumbar Disc Herniation}

by

\author{
Kazumori Arimura, Ken Takara, Hiroshi Fukuyama \\ and Masatoshi Matsuoka \\ Department of Orthopedic Surgery, Saiseikai Kumamoto Hospital
}

We have operated on 99 patients in recent 5 years.

The clinical follow-up of 86 cases was obtained by re-examination and 89 cases by questionnaires. They were followed for minimum of 6 months after operation. We evaluated these cases by the assessment of treatment of low back pain, tentatively, proposed by the Japanese Orthopedic Association Committee in 1984. Cosequently, more excellent cases were recognized in the antherior decompression group (with fusion) than the posterior decompression group (with non-fusion). There were distinct differences between the posterior group and the anterior group, regarding low back pain, gait, leaning forward, sitting and lifting or holding heavy objects. Moreover, postoperative disc narrowing was found in $51.2 \%$ of $\mathrm{L}_{4-5}$ discs and $33.3 \%$ of $\mathrm{L}_{5-} \mathrm{S}_{1}$ discs. And $46.3 \%$ of the former and $33.3 \%$ of the latercases had the residual low back pain.

\section{はじめに}

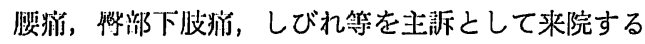

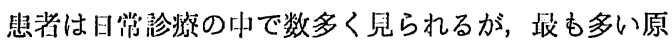
因は惟間板ヘルニアである，我々はこの腰部惟間板へ ルニアに対し，炤和 54 作 7 月より昭和 59 年 6 月末ま での 5 作間に 99 例（再手術例 5 例）飞観血的治嘫を 行なった. 今回術後 6 力月 以上経過した 89 例につき 後方除仼 (非固定) 群, 前方除圧 (固定) 群に分け, 術後成絬飞検討を加えた。

\section{対象症例，手術法及び手術成績}

压倒的に男性が多く，10才台のいわゆる若年性へル ニアが 9 例 (10.1\%)，60 才以上の高令者が 4 例 (4.5 \%) であるが，20才〜30才がやはり最む多く50 例で $56.2 \%$ \%占める. 我々の手術法の逝択は，(1) 著しい 椎間板变性，椎間货の狄少化のあるもの，(2)不安定椎 を有するもの，(3将来とも重労倒に耐えなければなら
ない青壮年者, (4)後方侵㦛による 椎間板切除術をう けた後の再発例等に前方固定術を行ない，それ以外の 症例には後方からのアプローチを行なっている. 尚, Love 法之前方固定術同時に行なっている症例は 1 例 であるが, てれは $\mathrm{L}_{4-5}$ の変性像を伴った不安定椎, $\mathrm{L}_{5}-\mathrm{S}_{1}$ の extrusive type のヘルニアに対して行なっ た. 手術高位は压倒的に $\mathrm{L}_{4-5}$ に多く諸家の報告之同 じである．手術成績を直接検診 86 例に対し，日整会 腰痛疾患治療成績判定基準（案，1984）亿基き，我々 は独自に, 秀 (29～27), 優 (26２2), 良 (21～18), 可 (17〜14), 不可 (13〜) と想定した結果, 術後経 過年数は 6 力月〜 5 年 3 力月, 平均 2 年 7 力月之短期 間ではあるが, 秀 37 例, 俊 38 例, 良 6 例, 可 5 例, 不可 0 例であった（表 1 ).

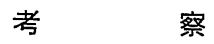

1）他覚所見及び膀腅機能の回復について 他覚所見及び膀脂機能の回復を後方除圧群之前方除 
表 1 腰部椎間板ヘルニアに対する観血的治療術後 6 力月以_l: 経邀例

(1979. $7 \sim 1984 . \quad 6$ )
1) 直 接 検 診: 86例
2) アンケート調查: 3例
3) 性别
男：62例
女: 27 例
4) 手術㭙年令: 15 72才平均35.2 才
5）調査時年 令：19 75才平均38.4才
6) 術後経過年数： 6 力月〜 5 年 3 力月
7) 手術々式 Love 法年 44 例 前方固定術 平均 2 年 7 力月 椎弓切除術 前方圆官得 81 Love 法十前方固定術 : 11 "
8）再于: 術例 Love 法+Love 泣:
Love 法十前方閏定術 椎弓切除術十放方固定術
9) 手術婯位

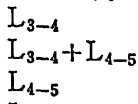
$\mathrm{L}_{1-5}$
$\mathrm{L}_{4}-\mathrm{L}_{5}-\mathrm{S}_{1}$
$\mathrm{L}_{5}-\mathrm{S}_{1}$
10）手術成綿：日整会。

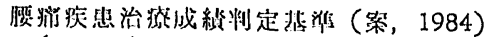
秀 $(29 \sim 27)$ ：37例 可 $(17 \sim 14): 5$ 例 擞 $(26 \sim 22): 38$ " 不可 $(13 \sim): 0$ ” 良 $(21 \sim 18): 6$ "

表 2 Prognosis of Clinical Signs and Urinary Bladder Function

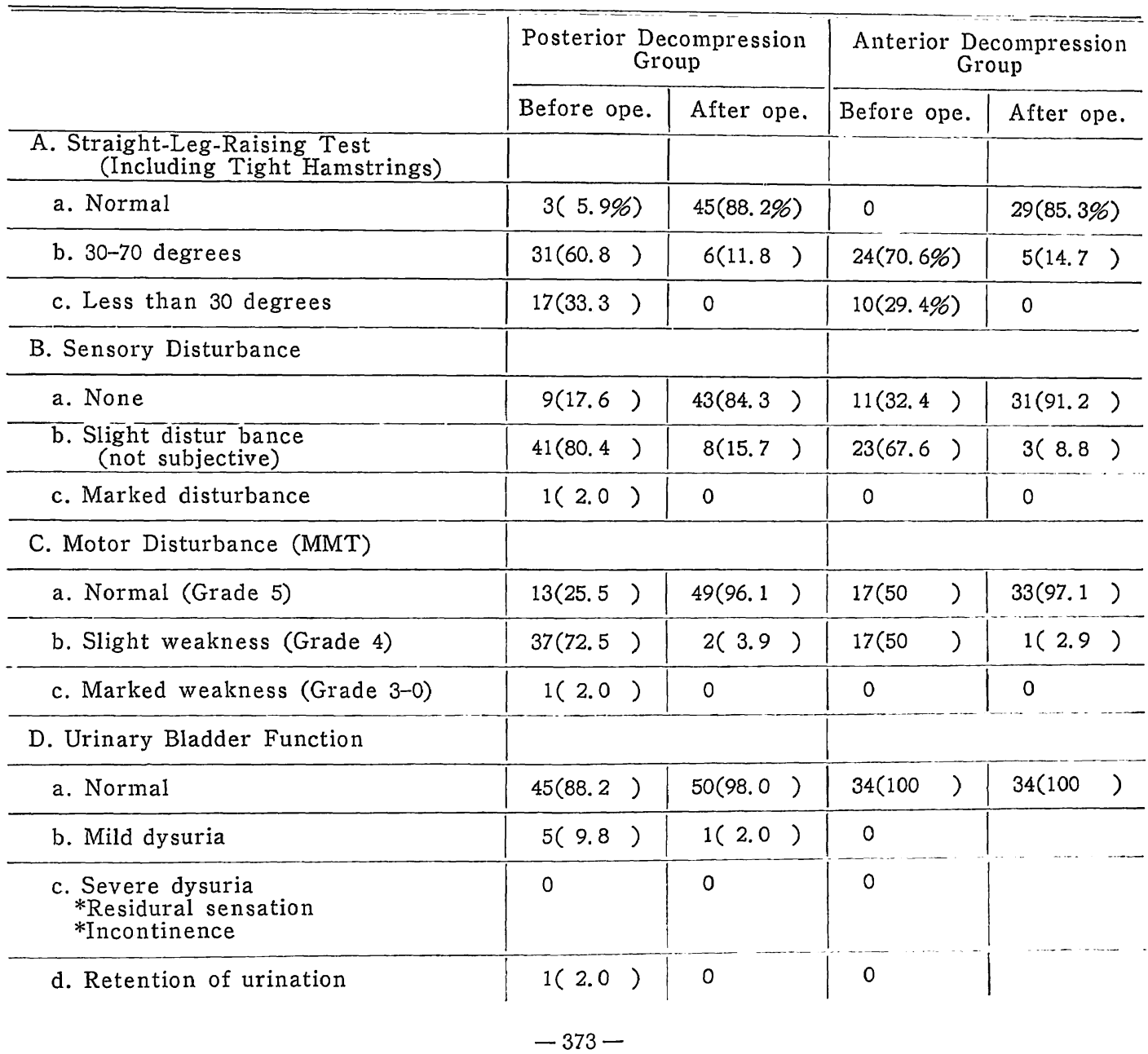


表３ミエログラムと手術法，手術成績

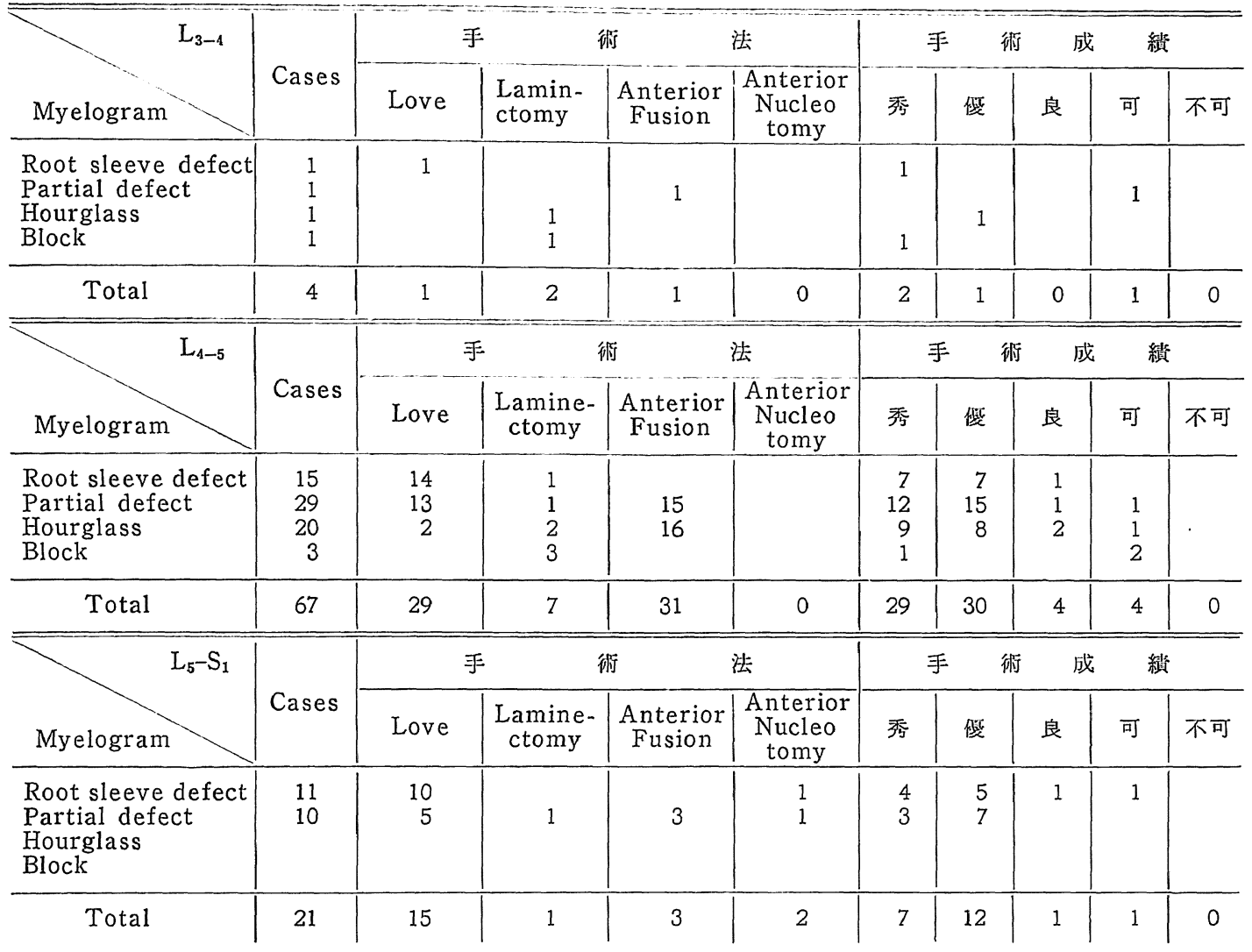

*再手術例は除く.

代群飞分け比恔してみると，SLR，知覚障害，筋力共 飞有意の差は認めなかった. 又䧛胱機能では，6例 （11.8\%）に障㕩を認めたが，羅喼高位は $\mathrm{L}_{4-5}$ block type hernia 2 例, $L_{4-5}$ partial defect type hernia 2 例, $\mathrm{L}_{3-4}$ block type hernia 1 例, $\mathrm{L}_{5}-\mathrm{S}_{1}$ partial defect type hernia 1 例である. 尿閉をき たした 1 例は， $\mathrm{L}_{4-5}$ block type hernia であるが, 尿閉発生後，約 10 日後に後方除仼術を行なったが， 術後約 1 年経過後の現在排尿遅延が残存し，手術成績 は可である（表 2).

2）ミエログラムと手術法, 手術成績について $\mathrm{L}_{3-4}$ 前方固定術成綞可例は，50才男性で， $\mathrm{L}_{3-4}$, $\mathrm{L}_{4-5} 2$ 椎間固定した症例であり, 移植骨片の㾤合不 全が原因と思和机る. 前任述べた前方除圧固定術の摘 応を基準にミエログラムを加え机ば Root sleeve defect type のヘルニアに秀例 $(46.7 \%)$ が多く良
い摘応之言える. 尚 2 椎間固定は 4 例あるが，他 3 例 は $\mathrm{L}_{4-5}-\mathrm{L}_{5}-\mathrm{S}_{1}$ 例であり, 骨癐合不全はこの 1 例のみ であり，他 3 例の手術成績は，秀 1 例，優 2 例である

(表 3 ).

3）自覚症状の改善について

自覚症状の改善を, 後方除仼群之前方除王群に分け 比較してみると，腰痛の全く無いむのが前方除圧群で は $55.9 \%$ \%あるが，後方除代群では $27.2 \%$ と明らか に劣っている. 下肢痛, しびれ及び歩行能力に関して も前方除圧群が秀れている. 婹椎々間板ヘルニア後方 術式では下肢痛の改善は良好であるが, 腰痛の改善が 少り術後成績を大きく左右しているてとは, 現在まで 内外の多くの報告が，遺残腰痛について論じているて とからしても明らかである（表 4).

4) ADL について

後方除圧群と前方除圧群に分け比較してみると，寝 
表 4 Improvement of Subjective Symptoms

\begin{tabular}{|c|c|c|}
\hline & $\left|\begin{array}{cc}\text { Posteridr } & \text { Decom- } \\
\text { pressior } & \text { Group }\end{array}\right|$ & $\begin{array}{l}\text { Anterior Decom- } \\
\text { pressior Group }\end{array}$ \\
\hline \multicolumn{3}{|l|}{ A. Low Back pain } \\
\hline a. None & $15(27.8 \%)$ & $19(55.9 \%)$ \\
\hline b. Occasional mild pain & $36(66.7)$ & $14(41.2)$ \\
\hline c. Frequent mild or occasional severe pain & $3(5.5)$ & $1(2.9)$ \\
\hline d. Frequent or continuous severe pain & 0 & 0 \\
\hline \multicolumn{3}{|l|}{ B. Leg pain and/or Tingling } \\
\hline a. None & $28(51.9)$ & $21(61.8)$ \\
\hline b. Occasional slight symptom & $22(40.7)$ & $13(38.2)$ \\
\hline c. Frequent slight or occasional severe symptom & $4(7.4)$ & 0 \\
\hline d. Frequent or continuous servere symptom & 0 & 0 \\
\hline \multicolumn{3}{|l|}{ C. Gait } \\
\hline a. Normal & $40(74.1)$ & $32(94.1)$ \\
\hline $\begin{array}{l}\text { b. Able walk farther than } 500 \text { meters while it results } \\
\text { in pain, tingling and/or muscle weakness }\end{array}$ & $14(25.9)$ & $2(5.9)$ \\
\hline $\begin{array}{l}\text { c. Unable to-walk farther than } 500 \text { meters owing to leg } \\
\text { pain. tingling and/or muscle weakness }\end{array}$ & 0 & 0 \\
\hline $\begin{array}{l}\text { d. Unable to walk farther than } 100 \text { meters owing'to leg } \\
\text { pain, tingling and/or muscle weakness }\end{array}$ & 0 & 0 \\
\hline
\end{tabular}

返り動作，立ち上がり動作，洗顔動作，歩行では余り 差は認めないが，中腰姿勢，又は立位の持続，1時間 位の長時間の坐位, 重量物の挙上又は保持動作等では やはり前方除王群が秀れていると言える（表 5).

5）術後椎間腔の狭少化と腰痛について

後方術後の椎間腔狭少化と腰痛の因果関係に関して は諸家の報告をみるが，我々あ前方除王群より後方除 王群に遺残性の腰痛が多いことは先に述べたが，乙れ で手術椎間，術後経過期間每に狭少化之腰痛の関係を みると, 術後約 1〜2 年経過後に狄少化が起とり始 め, $\mathrm{L}_{4}-{ }_{5}$ 又は $\mathrm{L}_{5}-\mathrm{S}_{1}$ 術後 2 年以上経過例にやや多 い. 尚, $\mathrm{L}_{5}-\mathrm{S}_{1}$ に2 例 Anterior Nucleotomy を施 行したが，現在まで狭少化は認めていない，椎間腔の 狭少化は椎間板の摘出量とある程度関係があると考え られるが，今回は調查していない（表 6).

6）年令, 前方, 後方術式別にみた手術成績につい $\tau$

年令から手術成績を前方, 後方術式別に見ると秀例 は後方除纴群では 10〜19才, 60 才以上, 30〜39才の
順で，前方除生群では 20〜29才，30〜39才，10〜19 才の順であるが, 後方 除王群では学俓年令の $20 \sim 30$ 才台の成績が少り, 逆に前方除王群では, この年令層 に秀れているが，加令的に良以下の症例が多い.

この年令層による成續の差は, 患者の活動性, 労働 内容, 脊柱の加令性変化等を考㫳する必要もあろう (表 7 ).

7) 再手術例について

症例 1.39 才男性. 両臂部下肢痛を主訴に来院. $\mathrm{L}_{4}-{ }_{5}$ にて完全ブロックし, Laminectomy によるへ ルニア摘出により軽快した. しかし術後経過良好であ ったが, 初回術後約 5 年経過後より左下肢痛, しびれ 出現し，同椎間にヘルニアを認めた為，前方より除王 固定した. 術後約 9 カ月経過の現在術後成績 秀であ る. 本症例は術後長期に経過が良好であってもてのよ うな再発例があるということは，臨床的にあ少なから 如問題を投げかけたといえるし，やはり残存䯣核の再 脱出が直接の原因であろうと思われる（図 1).

症例 2.21 才女性. 左臂部下肢痛を主訴に来院. 
表 5 Impairment of ADL

\begin{tabular}{|c|c|c|c|}
\hline & Grade & $\begin{array}{l}\text { Posterior Decom- } \\
\text { pression Group }\end{array}$ & $\begin{array}{l}\text { Anterior Decom- } \\
\text { pression Group }\end{array}$ \\
\hline a. Turn over while lying & $\begin{array}{l}\text { None } \\
\text { Moderate } \\
\text { Severe }\end{array}$ & $\begin{array}{c}49(90.7 \%) \\
5(9.3) \\
0\end{array}$ & $\begin{array}{l}28(82.4 \%) \\
6(17.6) \\
0\end{array}$ \\
\hline b. Standing & $\begin{array}{l}\text { None } \\
\text { Moderate } \\
\text { Severe }\end{array}$ & $\begin{array}{c}46(85.2) \\
8(14.8) \\
0\end{array}$ & $\begin{array}{c}27(79.4) \\
7(20.6) \\
0\end{array}$ \\
\hline c. Washing & $\begin{array}{l}\text { None } \\
\text { Moderate } \\
\text { Severe }\end{array}$ & $\left.\begin{array}{c}49(90.7 \\
5(9.3) \\
0\end{array}\right)$ & $\begin{array}{c}29(85.3) \\
5(14.7) \\
0\end{array}$ \\
\hline d. Leaning forwards & $\begin{array}{l}\text { None } \\
\text { Moderate } \\
\text { Severe }\end{array}$ & $\left.\begin{array}{c}21(38.9 \\
33(61.1 \\
0\end{array}\right)$ & $\begin{array}{c}20(58.8) \\
14(41.2) \\
0\end{array}$ \\
\hline e. Sitting (about I hour) & $\begin{array}{l}\text { None } \\
\text { Moderate } \\
\text { Severe }\end{array}$ & $\begin{array}{c}27(50.0 \\
24(44.4) \\
3(5.6)\end{array}$ & $\begin{array}{c}23(67.6) \\
11(32.4) \\
0\end{array}$ \\
\hline f. Lifting or holding heavy objects & $\begin{array}{l}\text { None } \\
\text { Moderate } \\
\text { Severe }\end{array}$ & $\left.\begin{array}{r}18(33.3 \\
33(61.1 \\
3(5.6\end{array}\right)$ & $\begin{array}{c}21(61.8) \\
12(35.3) \\
1(2.9)\end{array}$ \\
\hline g. Walking & $\begin{array}{l}\text { None } \\
\text { Moderate } \\
\text { Severe }\end{array}$ & $\begin{array}{c}50(92.6) \\
4(7.4) \\
0\end{array}$ & $\begin{array}{c}32(94.1) \\
2(5.9) \\
0\end{array}$ \\
\hline
\end{tabular}

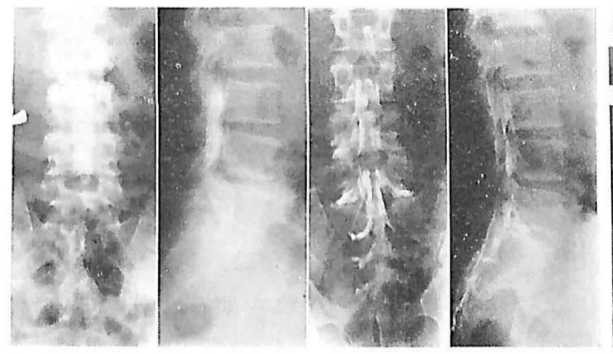

初回術交i Myelogram

C.C.：㞹桴部下肢坊，しびれ

S. 53-10-6: Laminectomy and Nucleotomy $\left(\mathrm{L}_{d-5}\right)$

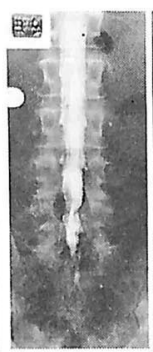

再手術前 Myelogram

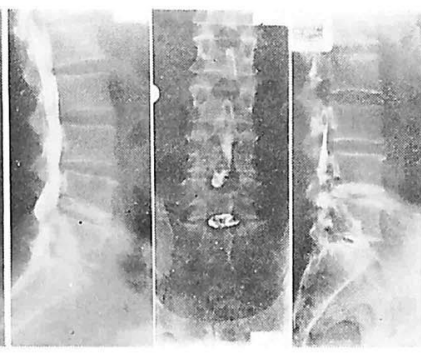

再手術前 Discogram

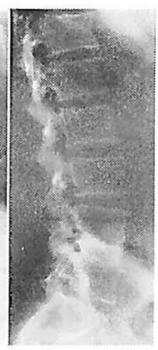

術後単純

C.C.：左下肢诵，しびれ

S. 59-2-7: Anterior Fusion $\left(\mathrm{L}_{1-5}\right)$

図 1 Case 1: T.Y. 39f 男手衐成績: 秀

約 3 力月問の保存療法にも柽快せず, Love 法にて 手術施行するむ怪快せず，逆传恶化した，再手術前 discography $ヒ \tau$ lateral hidden zone hernia 之媇断し，前方より除压固定し軽快した．術後約 4 年 経過の見在術後成績秀である。本症例屯へルニアの取 り残しが原因であるが，初回手術時に，Macnabの
言っている hidden zone hernia に気づいてお机 ば，再手術は防げたであ万うと思われる症例である. 尚, 残り 3 例の再手術例の原因は, 全く初歩的な左右 誤認 1 例, 他椎間後日発生 1 例, ヘルニア取り残し 1 例である(図 2 , 表 8 ). 
表 6 Postoperative Disc Narrowing and Low Back Pain

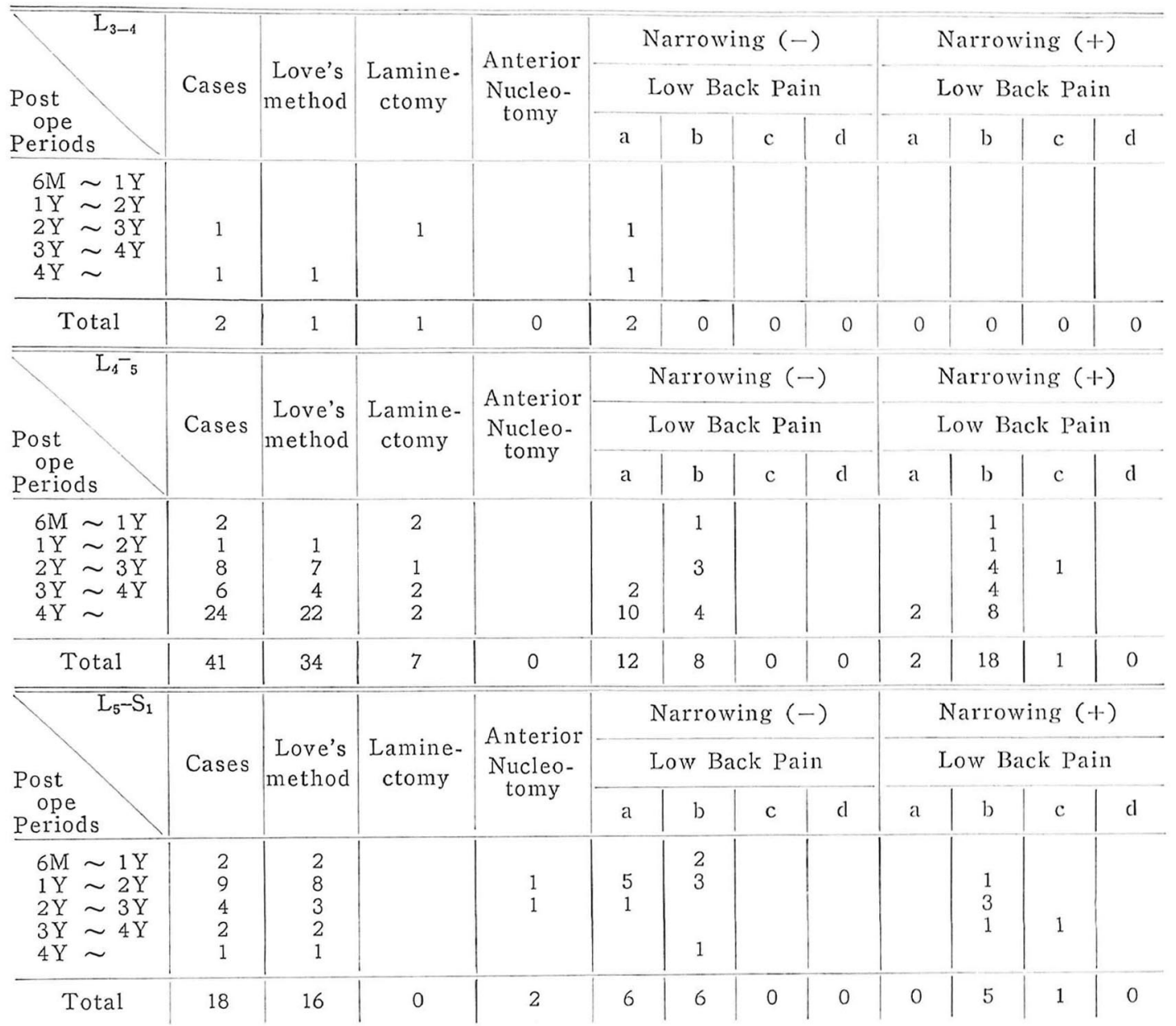

\%Low Back Pain

a. None

c. Frequent mild or occasional severe pain. b. Occasional mild pain

d. Frequent of continuous severe pain

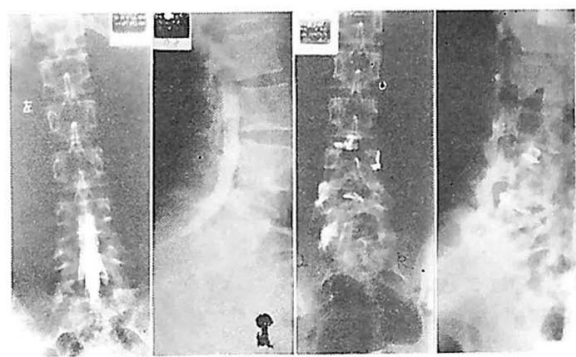

初回術前 Myelogram C.C.：左繁部下肢陪

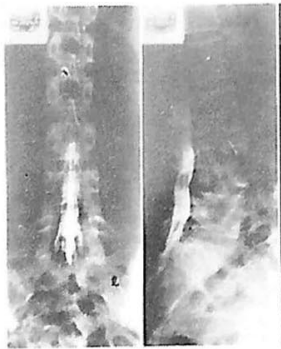

再手術前 Myelogram

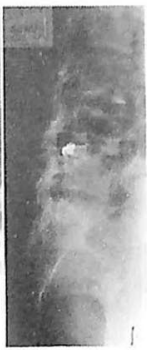

再于術解 Discogram

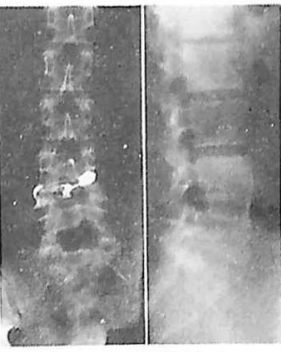

術後们純 X-P

S. 55-10-24: Anterior Fusion $\left(\mathrm{L}_{1-5}\right)$

S. 55-8-8: Love's Nucleotomy $\left(\mathrm{L}_{4-5}\right)$

図 2 Case 2:Y.H. 21才女手術成䋶：秀 
表 7 年令, 前方, 後方術式別にみた手術成絬 後方除正群

\begin{tabular}{|c|c|c|c|c|c|c|}
\hline 成絽 & 秀 & 偕 & 良 & 可 & 不可 & 計 \\
\hline $\begin{array}{l}10 \sim 19 \\
20 \sim 29 \\
30 \sim 39 \\
40 \sim 49 \\
50 \sim 59 \\
60 \sim\end{array}$ & $\begin{array}{l}3 \\
4 \\
5 \\
4 \\
1 \\
2\end{array}$ & $\begin{array}{l}3 \\
8 \\
6 \\
5 \\
1 \\
1\end{array}$ & $\begin{array}{l}1 \\
2 \\
1\end{array}$ & $\begin{array}{l}3 \\
1\end{array}$ & & $\begin{array}{r}7 \\
12 \\
13 \\
12 \\
3 \\
4\end{array}$ \\
\hline 計 & $\left(\begin{array}{c}19 \\
(37.3 \%)\end{array}\right.$ & $\begin{array}{c}24 \\
(47.1 \%)\end{array}$ & $\begin{array}{c}4 \\
(7.8 \%)\end{array}$ & $\begin{array}{c}4 \\
(7.8 \%)\end{array}$ & 0 & 51 \\
\hline
\end{tabular}

前方除任群

\begin{tabular}{|c|c|c|c|c|c|c|}
\hline $\begin{array}{l}\text { 成絽 } \\
\text { 年令 }\end{array}$ & 秀 & 偕 & 良 & 可 & 不可 & 計 \\
\hline $\begin{array}{l}10 \sim 19 \\
20 \sim 29 \\
30 \sim 39 \\
40 \sim 49 \\
50 \sim 59 \\
60 \sim\end{array}$ & $\begin{array}{l}1 \\
6 \\
8 \\
3\end{array}$ & $\begin{array}{l}1 \\
2 \\
5 \\
5\end{array}$ & $\begin{array}{l}1 \\
1\end{array}$ & 1 & & $\begin{array}{r}2 \\
8 \\
13 \\
9 \\
2 \\
0\end{array}$ \\
\hline तो & $\begin{array}{c}18 \\
(52.9 \%)\end{array}$ & $\left(\begin{array}{c}13 \\
(38.3 \%)\end{array}\right.$ & $\begin{array}{c}2 \\
(5.9 \%)\end{array}$ & $\begin{array}{c}1 \\
(2.9 \%)\end{array}$ & 0 & 34 \\
\hline
\end{tabular}

* Love 法十帡方固定術例は除く.

図 3 Macnab I. (J. Bone \& Joint Surg., 53-A, 900, 1971 より)

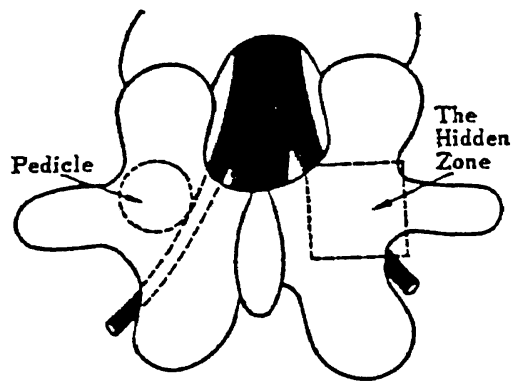

結語

1）当科における腰部椎間板へルニア術後，6力月 以上経過した㨁接検荆 86 , アンケートのみの回答 3 例を日整会涺痛疾腎治療成維判定基準（桇，1984）に

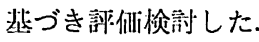

2）手術成絽は後方除压（非国定）群では，秀37. 3 $\%$, 传 $47.1 \%$, 这 $7.8 \%$, 可 $7.8 \%$, 前方除圧（固 定）群では，秀 $52.9 \%$ ，傮 $38.3 \%$ ，良 $5.9 \%$, 可
2.9\%であり秀例が前方除圧（固定）群に多かった. 又全例に不可例はなかった.

3）他党症状は, 後方除圧（非固定）群, 前方除圧 （固定）群の間に明白な差は見い出し得なかったが， 自覚症状及び ADL 上の, 腰痛, 歩行能力, 中腰姿 勢又は立位の持続, 長洔間坐位, 重量物の挙上又は保 持等の項で有意差を認めた.

4) 後方除任（非固定）群では $\mathrm{L}_{4}{ }^{-5}$ 例で $51.2 \%$, $\mathrm{L}_{5}-\mathrm{S}_{1}$ 例で $33 \%$ 術後椎間腔の狭少化を認め, 各々 $46.3 \%, 33.3 \%$ 遣残腰痛を認めたが, 狭少化を認 めても腰痛のない症例むあり，それ以外の要素にも影 響されるすのと思われる。

\section{参考文 献}

1）新井实・他：術後艮期に経過良好であった後 に同一レベルに再発した腰椎々間板ヘルニアの3 例, 整形・災害外科, 26: 953-957, 1983.

2）排上駿一，松井宣夫：前方術式に上る腰椎々間 板ヘルニアの手術的治療, 災㕩医学, 18:76-89, 1975.

3）金田清志：椎間板ヘルニアの手術的治療（座談 会), 臨整外, 14:1136-1148, 1979.

4）河端正也：腰椎々間板へルニアに対する Love 法手術とその灙隔成䋊, 災害医学, 18：49-53, 1975.

5) Macnab, I.: Negative disc expioration, an analysis of the cause of nerve-root involvement in 68 patients. J. Bone \& Joint Surg., 53-A : 891-903, 1971.

6）中野 昇: 腰椎々間板ヘルニア再手術例の検討 災害医学，21：1319-1325，1978.

7) 中野昇：腰部椎間板変性に対する前方摘出術 の椎間腔㹟少, 整形・災害外科, 27:201-205, 1984.

8）大村和久：腰椎々間板ヘルニア術後成紹の検討 災㕩医学, 20：1087-1094, 1977.

9）三枝 修・他：䁏椎々間板ヘルニア後方術式の 長期遠隔成䋊の検討および成絈向上への一対策に ついて, 整形・災輩外科, 23：1725-1738, 1980.

10） 戸山芳炤・他：腰部椎間板へルニア（主にLove 法）に対する再手術法としての前方固定一再手術 前ミエロとディスコからみた適応と限界, 臨整 外, 16: 365-371, 1981.

11）辻 陽雄 - 他：腰部椎間板障害再手術の原因之 刘策, 整形外科 Mook, 11 : 266-285, 1979.

12）塚西茂炤・他：腰椎々間板ヘルニアの術後経過 一特に椎間腔狭少化について一, 中部整災誌， 21 : 1223-1225, 1980. 